\title{
Benda Terdaftar dalam Konstelasi Hukum Indonesia
}

\author{
Moch. Isnaeni
}

\begin{abstract}
Although the Waqaf Board (Badan Waqaf) has accurately broken the model of the distribution of wealth down, the need of societies, due to the acceleration of the development in this era, cannot be adapted to the available device model. Therefore, many parties presume that these material cases are necessary to be seriosly paid attention, especially on the distribution of the types of listed and unlisted wealth. The distribution is executed by. maintaining the classification of movable and immovable objects, so the target of straightening the law of national wealth is attained.
\end{abstract}

\section{Pendahuluan}

Dari kehidupan nyata sehari-hari, setiap anggota masyarakat untuk memenuhi segala kebutuhan ataupun pencapaian tujuan, akan selalu terkait dengan benda, dan terbukti benda tak pernah dapat lepas dari kegiatan hidup manusia dalam kurun waktu kapan pun, dan pada taraf peradaban yang mana saja. Dengan posisi seperti itu, betapa pentingnya peranan benda dalam kehidupan sosial. Tanpa kehadiran benda, kiranya menjadi langka kehidupan manusia akan utuh terpadu sebagai gugus masyarakat. Benda selaku penyangga kebutuhan manusia dalam menempuh kehidupan sosialnya, mempunyai peran yang sangat strategis. Hampir, semua tujuan yang ingin dicapai oleh seseorang, benda, sebagai sarana akan ikut tampil menimpali upayanya itu tanpa bisa dielakkan barang sejenak. Betapa jelas bahwa kegiatan orang dalam kesehariannya selama menempuh hayat, tak pemah lepas dari peran' serta benda. Bahkan dengan benda yang dimiliki itu pula orang dapat melakukan pelbagai perbuatan terhadapnya. Mulai dengan perilaku menjualnya, menyewakan, menukarkan dengan benda lain, menghadiahkan, menjaminkannya, menitipkan, dan sebagainya. Sejalan dengan banyaknya perbuatan orang yang berobjek pada benda, maka diperlukan aturan guna memperlancar dan memudahkan penyelenggaraan kegiatan-kegiatan itu. Hukum sebagai salah satu jenis aturan sosial, juga memperhatikan benda ini selaku objeknya 
mengingat sedemikian lekat manusia itu kepadanya. Namun dikarenakan benda yang ada dalam kehidupan bermasyarakat itu sedemikian banyak jenis dan macamnya, lalu juga begitu beragam perbuatan atau transaksi yang dilakukan manusia terhadap benda miliknya itu, maka hukum perlu mengadakan suatu sistematisasi sebagai salah satu tuntutan hakekat peraturan. Ragam benda yang tak terhitung jumlahnya, perlu disederhanakan dalam katagori-katagori tertentu sehingga lebih mudah mengatur dan menyelesaikan transaksinya. Pada gilirannya, sistematisasi yang dilakukan oleh hukum akan membuahkan konsekuensi berantai terhadap aturan-aturan lanjut yang berkait dengan mobilitas benda itu sendiri dalam kehidupan bermasyarakat.

Sejalan dengan uraian betapa strategisnya kedudukan benda, maka dalam kehidupan kelompok yang selalu dijumpai adanya hukum, salah satu bahagiannya pasti akan mengatur pula tentang seluk beluk benda ini. Pengaturan terhadap benda selalu akan dapat dijumpai dalam sistem hukum di manapun sesuai dengan nilai-nilai dan dasar falsafi yang dianut. Walaupun susunan masyarakat masih dalam taraf sederhana sekalipun, tentu sudah punya aturan yang menyangkut eksistensi benda sebagai objeknya. Bahkan sesuai dengan perkembangan zaman, juga didorong kemajuan teknologi serta munculnya penemuan-penemuan baru, telah memaksa beberapa negara sering kali harus mengubah aturan hukumnya terhadap masalah benda ini, dengan tujuan tak lain untuk mendatangkan kesejahteraan yang lebih baik bagi lingkungannya. Tidak dapat dielakkan aturan hukum yang menyangkut benda kian hari terasa semakin penting dirasakan orang, sebab demikian rumit sudah keberadaan benda tersebut setelah dijadikan objek pelbagai transaksi yang kian beragam. Untuk itu kajian yang menyangkut hukum di seputar benda dengan segala peristiwa transaksinya, menjadi semakin menarik minat banyak kalangan. Pihak yang berkepentingan terhadap seluk beluk aturan hukum yang menyangkut benda ini, tak sebatas pada kalangan orang hukum saja, juga para pelaku ekonomi mencurahkan minatnya tak kalah deras. Secara faktual transaksi-transaksi kebendaan yang dimotori oleh kepentingan ekonomis, menuntut adanya suatu efisiensi. Untuk keperluan itu sering kali dibutuhkan bantuan sarana hukum agar ikut mewujudkannya secara optimal. Bantuan yang diperlukan semacam ini baru bisa diulurkan manakala aturan yang dimiliki oleh hukum itu sendiri memiliki bobot kepastian hukum dan keadilan. Oleh karena itu, tidak begitu keliru kalau sering diperbincangkan bahwa tuntutan efisiensi para ekonom, sebenarnya bernada sama dengan masalah kepastian hukum serta keadilan bagi kalangan orang hukum. Matra seperti ini, akhirnya menunjukkan bahwa antara bidang hukum dan ekonomi menjadi akrab dalam upaya menangani pelbagai masalah yang muncul dalam kehidupan sosial. Pertukaran pandang dan ide di antara kedua bidang tersebut pada dewasa ini sudah bukan hal yang asing lagi, bahkan sudah terasa sebagai suatu kebutuhan. Pada satu sisi, faktor ekonomi kuat sekali mempengaruhi struktur hukum yang berlaku, demikian pula sebaliknya, bahwa pada sisi yang lain hukum juga tak kalah banyak memberikan sahamnya untuk memacu perkembangan ekonomi. Hal ini 
sebenarnya sudah cukup lama disimak oleh Weber dengan sekelumit pernyataannya:

Law, it is insisted, constitutes as sphere of autonomous social reality which, while influenced in its development by economic forces, in turn also influences the economic (and indeed other) processes within society. This autonomy is thus relative rather than absolute. ${ }^{1}$

Pemerintah Indonesia harus segera membenahi sistem hukum-benda nasional, karena tatanan benda yang ada sekarang ini masih tak menentu. Mengatur Hukum Benda yang sifatnya lebih netral, dalam arti tidak banyak bersinggungan dengan sentimen masyarakat ataupun aspek spiritual seperti halnya hukum perkawinan, maka kendala yang dihadapi tidak begitu besar. Sejalan dengan uraian ini kiranya benar apa yang dikemukakan kalau aspek kebendaan ini dibenahi untuk diatur lebih akurat sesuai tuntutan kebutuhan, kiranya tidak akan banyak menimbulkan gejolak sosial. Mariam Darus dalam salah satu karyanya menyatakan: "Jika hukum keluarga bersifat non netral, maka Hukum Benda sebagai bagian dari hukum harta kekayaan bersifat netral.".

Menunda lebih lama tentang pembentukan hukum benda nasional hanya membuahkan ketidakpastian yang amat mengganjal, sebab selama ini beberapa pihak telah menelorkan produk perundangan yang menyinggung kedudukan benda, tanpa dapat menjelaskan aturan tersebut didasarkan pada prinsip-prinsip yang mana. Prịnsip-prinsip yang dibutuhkan sebagai landasan utama belum lagi ada, sehingga keterdesakan untuk membuat peraturan yang dibutuhkan, memaksa ketentuan-ketentuan di seputar benda yang dijadikan objeknya, menjadi tanpa pegangan kokoh. Bagaimana akurasi itu akan terwujud kalau yang digarap justru bagian muara dulu, sedang apa dan bagaimana hulunya belum lagi jelas. Ini nampak pada penggarapan UU No.5 Tahun 1960 (UndangUndang Pokok Agraria), UU No.16 Tahun 1985 (Undang-Undang Rumah Susun), dan UU No.15 Tahun 1992 (Undang-Undang Penerbangan). Semua produk perundangan itu mestinya didasarkan pada aturan pendahulunya yakni hukum benda nasional yang menyediakan prinsip-prinsip utama tentang kebendaan. Karena ketiadaan aturan yang berisi prinsip kebendaan nasional, maka apa yang tersaij dalam produk perundangan tersebut dalam beberapa hal termasuk di antaranya masalah penjaminannya menimbulkan persoalan-persoalan yang kadang rumit, bahkan sering bersifat kontradiktif. Beberapa benda modal yang mempunyai posisi strategis dalam aspek ekonomi, karena ketiadaan dasar yuridik yang pasti, masálah pengagunannya sering memancing perbincangan sengit. Di satu sisi, meski pembentuk undang-undang punya kewenangan untuk menggariskan kebijakannya menetapkan sesuatu dengan aturan tertentu, namun kriteria yuridik seharusnya tetap perlu dihadirkan sebagai landasan tumpuan pengambilan kebijakan tersebut. Sampai

${ }^{1}$ Alan Hunt. 1978. The Sociological Movement in Law. London: Billing and Sons Ltd. HIm. 118.

${ }^{2}$ Mariam Darus Badrulzaman. 1983. Mencari Sistem Hukum Benda Nasional. Bandung:Alumni. HIm. 30. 
dengan sekarang prinsip-prinsip hukum yang berlaku terhadap benda di Indonesia masih bersifat mendua, dan mereka berjalan beriringan kendati punya pola yang berbeda. Kondisi ini sudah pula ditengerai oleh Subekti:

Sebagaimana diketahui, Hukum perdata kita masih tetap dihinggapi ciri dualisme. Hukum Adat (tidak tertulis) untuk golongan pribumi, hukum kodipikasi (Burgerlijk Wetboek dan Wetboek van Koophandel) untuk golongan non pribumi. Dalam pada itu hukum mengenai bumi dan air (Hukum Tanah) sudah berhasil diseragamkan untuk semua golongan dalam UndangUndang Pokok Agraria (Nopember 1960), yang berorientasi pada Hukum Adat. ${ }^{3}$

Dimensi seperti itu akan membuah-kan ketidakpastian hukum, pada gilirannya akan menimbulkan kesan bahwa sistem hukum yang tersedia tak mampu memberikan pegangan yang mantap untuk sarana pamungkas pemecah problema. Terlebih lagi kalau kesan ini muncul pula di kalangan para pelaku ekonomi, dianggapnya tak memenuhi patokan efisiensi seperti yang diharapkan.

\section{Pengaturan Benda dalam Hukum Adat}

Eksistensi hukum adat yang non statutair umumnya selalu diperlawankan dengan hukum tertulis memiliki keluwesan dalam gaya hidupnya, sehingga akan lebih mudah menyesuaikan diri dengan perkembangan dan ini hampir mencakup di semua bidang seperti Hukum Keluarga, Hukum Waris, Hukum Perkawinan, Hukum Tanah dan sebagainya. Namun penyesuaian demikian ini pada dasarnya secara riil lewat putusan-putusan hakim yang boleh dikata merupakan langkah pembinaan terhadap Hukum Adat yang dilakukan secara berkesinambungan. Untuk segi ini Subekti pernah berulas dalam salah satu tulisannya:

"Mengenai pembinaan Hukum Adat, tidak ada timbul suatu persoalan: seluruhnya merupakan bidang pembinaan yurisprudensi seperti sediakala. Pembinaan yang sesuai dengan kemajuan zaman dapat kita ikuti dalam semua bidang: Hukum Keluarga,. Hukum Perkawinan, Hukum Waris, Hukum Tanah,....4

Menyangkut pengaturan terhadap benda, ternyata Hukum Adat hanya mengenal pembagian yang cukup sederhana, yakni benda berupa tanah dan benda bukan tanah. Pembedaan demikian ini diakui hampir oleh segenap penulis. Menurut Mariam Darus Badrulzaman di dalam Hukum Adat benda dibedakan dalam tanah dan yang bukan tanah. ${ }^{5}$ Juga Sri Soedewi menandaskan: bahwa menurut hukum adat hanya mengenal pembedaan benda atas tanah dan bukan tanah. Tidak mengenal pembedaan atas benda bergerak dan benda tak bergerak, benda yang berwujud dan benda yang tak

${ }^{3}$ R. Subekti. 1983. Hukum Adat Indonesia Dalam Yurisprudensi Mahkamah Agung). Bandung: Alumni. HIm. 108.

4/bid. h. $108-109$.

${ }^{5}$ Mariam Darus Badrulzaman. Op. Cit. HIm. 34. 
berwujud dan lain-lain. ${ }^{\text {"6 }}$ R.Soepomo dalam hasil penelitiannya di kawasan Jawa Barat menyatakan bahwa di Lebak Selatan (Banten) orang-orang yang mengerjakan huma, yang telah menanam pohon buah-buahan dan tanaman keras lainnya di tanahnya, mempunyai hak huma. Oleh penduduk daerah hukum mereka dianggap sebagai pemilik tanaman itu. $^{7}$

- Dengan pola pembagian benda seperti itu, maka selanjutnya dalam Hukum Adat hanya dikenal asas pemisahan horisontal. Mengingat Hukum Adat tidak mengenal pembagian benda berupa benda bergerak-benda tidak bergerak, maka asas accessie juga tidak diikutinya. Ini pernah dikemukakan pula oleh Sri Soedewi bahwa dalam hukum adat berlaku asas pemisahan horizontal yang memungkinkan pemilikan dan peralihan benda-benda di atas tanah itu terlepas dari tanahnya. Hukum adat tidak mengenal asas accessi. ${ }^{8}$

Pola pembagian benda dalam hukum adat yang sederhana seperti itu akhirnya tidak banyak melahirkan konsep-konsep yang bisa mengembangkan sistem hukum benda di kalangan masyarakat adat. Tambahan lagi pembedaan benda tersebut orientasinya tidak bertumpu pada pertimbangan-pertimbangan aspek ekonomi beserta pengembangannya yang terus melaju, sehingga ketika lahir era ekonomi pasar perangkat aturan benda dalam hukum' adat tak mampù mengejar ketertinggalannya."

Hukum adat dalam membagi jenis benda sebagaimana terurai di atâs, mengamati pola itu kiranya kurang meyakinkan untuk dapat dipakai sebagai landasan membenahi aturan hukum benda nasional. Terlebih lagi pembedaan benda tersebut tak dapat dipergunakan sebagai ukuran untuk ikut mengkatagorisasikan hasil-hasil penemuan teknologi baru yang terus mèngalir. Konfigurasi ini kian diperjelas lagi dengan sikap pemerintah dalam politik hukumnya bahwa pada erà pembanigunan hukum akan sebanyak mungkin dibentuk hukum tertulis. Ini terkesan dari niat pemerintah untuk -menempuh pembaharuan hukum dengan jalan mengadakan kodifikasi, meskipun secara parsial. Sehubungan dengan itu Mariam Darus Badrulzaman yang menyatakan bahwa pada umumnya ahli hukum kita telah sepakat bahwa dalam bidang hukum perdata akan dipergunakan kodifikasi. ${ }^{9}$

Dalam pembentukan kodifikasi ini, eksistensi hukum adat juga akan diperhatikan sebagai sailah satu sumber hukum. Kalau hukum adat sudah dipakai sebagai salah satu sumber p̈embentukan hukum nasional, makä hukum adat itu telah terserap sebagai hukum nasional. Dengan corak seperti ini maka landasan utama penerapan hukum Indone-

\footnotetext{
' Sri Soedewi Masjchoen Sofwan. 1980. Hukum Jaminan dilndonesia, Pokok-pokok Hukum Jaminan dan Jaminan Perorangan. Yogyakarta: Liberty. HIm. 1.

${ }^{\top} R$. Soepomo. 1982. Hukum Perdata Adat Jawa Barat. (terjemáhan Ny. Nani Soewondo). Jakarta: Jambatan. HIm: 76.

${ }^{8}$ Sri Soedewi Machjsoen Sofwan. Op. Cit. Him. 16.

${ }^{9}$ Mariam Darus Badrulzäman. Op. Cit. HIm. 7.
} 
sia nanti akan bertumpu pada hukum tertulis, sedang peranan hukum tak tertulis kiranya berlaku sebagai pelengkap, dalam arti baru tampil kalau hukum tertulis tidak mengatur atau aturan yang ada di dalamnya ternyata tak memadai. Namun ini jangan diartikan bahwa hukum adat tidak dipakai lagi sebagai salah satu sumber hukum. Dalam banyak hal kawasan hukum adat masih tetap dapat memberikan andilnya bagi para hakim untuk mencari keadilan atas perkara-perkara yang diajukan kepadanya. Sebagaimana telah disinggung pada bagian depan, karena pola hukum adat orientasi utamanya tidak pada aspek ekonomi, maka sukar diharap bahwa hukum adat akan bisa banyak memberikan perannya kepada pemecahan problemaproblema hukum yang sarat dengan muatan bisnis.

\section{Penggolongan Benda Menurut BW}

Kalau disimak dengan seksama, BW membagi benda relatif lebih banyak dan cukup rinci. Secara garis besar jenis-jenis benda yang dikenal dalam BW adalah sebagai berikut:

1. Benda berujud dan benda tidak berujud (lichamelijke zaken-onlichamelijke zaken, Pasal 503);

2. Benda bergerak dan benda tidak bergerak (roerende zaken-onroerende zaken, Pasal 504);

3. Benda habis pakai dan benda tidak habis pakai (verbruikbare zaken-onverbruikbare zaken, Pasal 505);

4. Benda dalam perdagangan dan benda di luar perdagangan (zaken in de handelzaken buiten de handel, Pasal 1332);
5. Benda yang sudah ada dan benda yang masih akan ada (toekomstige zakentegenwoordige zaken, Pasal 1334);

6. Benda yang dapat dibagi dan benda tidak dapat dibagi (deelbare zaken-ondeelbarezaken, Pasal 1163).

7. Benda yang dapat diganti dan benda yang tidak dapat diganti (vervangbare zakenonvervangbare zaken, Pasal 1694).

Cara pembagian benda seperti tersebut di atas kalau dibandingkan dengan hukum adat memang sangat berbeda, sehingga pembagian benda dalam BW mempunyai konsekuensi lanjut yang melahirkan konsepkonsep beragam dalam bidang-bidang lainnya yang terkait, terutama untuk jenis pembagian benda bergerak-benda tidak bergerak.

Walaupun banyak pembagian jenis benda yang dikenal $\mathrm{BW}$, ternyata yang paling penting dan sangat menonjol adalah pembagian jenis benda bergerak-benda tidak bergerak. Namun untuk pembedaan beberapa jenis benda yang lain, seperti benda dalam perdagangan-benda di luar perdagangan, benda dapat dibagi-benda tidak dapat dibagi, ada yang berpendapat bahwa sebenamya hal itu tidak perlu. Soetan Malikoel Adil menyatakan:

"Juga saya tidak dapat mengerti, apa faedahnya mengatur dalam undangundang bahwa ada benda yang dapat dibagi dan yang tidak dapat dibagi (deelbare en ondeelbare zaken). Semua orang kan telah tahu apa yang dimaksud dengan istilah tersebut. Semuanya itu adalah akibat dari suka berbicara. ... Jadi juga tentang perbedaan yang diadakan dalam Buku Hukum Perdata mengenal zaken in de handel en zaken buiten de handel saya sependapat dengan Asser- 
Scholten II halaman 23 dan seterusnya, yang mengatakan alles wat zaak is, kan voonwerp van private rechten zijn. ${ }^{{ }_{110}}$

Tentang pembedaan benda bergerakbenda tidak bergerak banyak kalangan mengakui bahwa pembagian ini memang perlu dan kenyataannya negara-negara lainpun mengenalnya pula. Lagi pula pembedaan jenis benda bergerak - benda tidak bergerak ini, terbukti membawa akibat berbeda dalam banyak lapangan.

Barang siapa yang menguasai benda bergerak dianggap pemilik sebagaimana ditetapkan dalam Pasal 1977 BW itu memang banyak mendatangkan manfaat, sehingga mobilitas benda bergerak sebagai obyek transaksi menjadi lebih lancar dan efisien. Sebaliknya andai kata tidak ada asas seperti itu kemungkinan besar transaksi-transaksi di dunia niaga akan banyak terhambat karenanya.

\section{Benda Terdaftar:}

\section{Suatu Perkembangan Baru}

BW mengenal demikian banyak pembagian jeriis benda, namun dalam perkembangan masyarakat lebih lanjut menunjukkan kecenderungan adanya kehendak untuk menambah pembiagian benda tersebut dengan jenis lain yang baru yakni benda terdaftar-benda tidak terdaftar. Gejala ini merebak setelah peristiwa kodifikasi BW, meskipun harus diakui bahwa pembagian benda bergerak dan benda tidak bergerak tetap diperlukan. Hal ini pernah pula diungkap oleh Sri Soedewi: ,

"Negara-negara Eropa Kontinental sejak resepsi Hukum Romawi hingga sekarang tetap menganggap penting arti pembedaan benda bergerak dan benda tidak bergerak. Meskipun di samping itu mulai dikenal juga pentingnya pembedaan benda terdaftar dan benda tak terdaftar register goederen en niet register goederen, namun masih menganggap penting pembedaan antara benda bergerak dan benda tetap. ${ }^{\text {"11 }}$

Hal senada ditemui pula di Nederland sebab di samping tetap mempertahankan pembedaan jenis benda bergerak-benda tidak bergerak, dalam BW barunya mulai pula mencantumkan adanya benda terdaftarbenda tidak terdaftar. Ini disinggung oleh Mariam dengan menyatakan bahwa Nederland dalam KUH Perdatanya yang baru, di samping tetap mempertahankan pendirian lama, yaitu mengenal pembedaan benda tetap dan bergerak, juga menambahkan pembedaàn benda terdaftar dan tidak terdaftar. ${ }^{12}$

Walaupun BW belum mengatur secara khusus, namun sebenamya kalau hendak dikaji lebih seksama, kegiatan mendaftar bendabenda tertentu yang diharuskan oleh peraturan perundangan sudah cukup lama dikenal dan ditangani berdasar ketentuan khusus sehubungan dengan hal ini Riduan Syahrani menyatákan:

"Pembagian atas benda terdaftar 'dan benda yang tidak terdaftar tidak dikenal

\footnotetext{
${ }^{10}$ Soetan Malikoel Adil. 1962. Hak-hak Kebendaan, Pembangunan. Jakarta. Hlm. 15.

"Sri Soedewi, Machsjoen Sofwan. Op. Cit. Hlm. 53.

${ }^{12}$ Mariam Darus Badrulzaman. Op. Cit. HIm. 40.
} 
dalam sistem hukum perdata (BW). Pembagian benda macam ini hanya dikenal beberapa waktu kemudian setelah BW diķodifikasikan dan diberlakukan. Benda-benda yang harus didaftarkan diatur dalam berbagai macam peraturan yang, terpisah-pisah seperti peraturan tentang pendaftaran tanah, peraturan tentang pendaftaran kapal, peraturan tentang pendaftaran kendaraan bermotor, dan lain sebagainya. ${ }^{.13}$.

Menyangkut benda tidak bergerak berupa tanah sudah lama dikenal sistem pendaftarannya dalam suatu register umum yang sengaja disediakan untuk keperiuan itu. $\mathrm{Hal}$ ini sudah dianggap lazim, karena kepemilikan dan segala pembaharuannya diperlukan suatu kepastian yang jelas meski kadang nampak berbelit.

Berdasar perkembangan sejarah, asal mula pendaftaran tanah ini diperlukan untuk kepentingan fiskal. Pendaftaran yang berasal dari kata cadastre, merupakan suatu istilah teknis yang hendak menggambarkan secara seksama tentang luas, nilai, dan kepemilikan maupun hak-hak lain atas sebidang tanah. Dengan pendaftaran itu akan diketahui dengan tepat tentang siapa pemilik dari tanah yang bersangkutan, hak apa yang melekat pada tanah tersebut, dan akan dilakukan pencatatan pula bila tanah itu dialihkan, selain juga berisi tentang nilai dari tanah tersebut demi menentukan berapa besar fiskal yang akan dikenakan.
Bila ditelusuri lebih jauh lagi, kata cadastre berasal dari bahasa Latin capitastrum yang berarti suatu capita, atau unit, atau register yang dibuat untuk keperiuan perpajakan bagi tanahtanah Romawi. ${ }^{14}$ Dalam perkembangan lanjutnya, kadaster atau pendaftaran itu tidak hanya menyangkut kepentingan fiskal belaka; berarti lebih bersifat administratif, tetapi akhirnya berguna juga bagi aspek keperdataan. Dengan pendaftaran itu di dalam register yang disediakan, tercatat tentang siapa pemilik, hak apa yang melekat, dan juga segala perubahan keadaan tanah itupun akan direkam, maka dengan sendirinya keperluan dari aspek perdata menjadi berperan pula. Dengan demikian pendaftaran itu tidak sekedar tindakan administratif belaka, tetapi telah pula menjangkau hakekat kepentingan keperdataan yang teramat sentral. Sejalan dengan hal tersebut. Bachtiar Effendi menyatakan:

"Perbuatan hukum pendaftaran tanah/ pendaftaran hak atas tanah adalah suatu peristiwa penting karena menyangkut segi hak keperdataan seseorang dan bukannya hanya sekedar tindakan administratif belaka. Hak keperdataan adalah merupakan hak azasi seorang manusia yang harus dijunjung tinggi dan dihormati oleh sesama manusia lainnya dalam rangka terwujudnya kedamaian dalam ikatan hubungan kemasyarakatan."15

${ }^{13}$ Riduan Syahrani. 1985. Seluk Beluk dan Asas-asas Hukum Perdata. Bandung:Alumni. Hlm. 123- 124 ${ }^{14} \mathrm{AP}$ Parlindungan. 1990. Pendaftaran Tanah di Indonesia. Bandung: Mandar Maju. HIm. 11.

${ }^{15}$ Bachtiar Effendi. 1981. Pendaftaran Tanah di Indonesia dan Peraturan-peraturan Pelaksanaannya. Bandung: Alumni. Him. 29 - 30. 
Dengan pendaftaran, kepemilikan atas tanah itu secara umum khalayak ramai akan tahu siapa yang mempunyai kewenangan kebendaan atas tanah yang bersangkutan. Ini merupakan salah satu poros penting dalam bidang hukum benda yang pada kenyataannya menyangkut permasalahan pokok tentang siapa pemiliknya, terjawab secara pasti dengan adanya pendaftaran itu. Bukankah hal ini menonjolkan aspek keperdataan yang intinya memang sangat penting, kendati tujuan semula hanya untuk menentukan besarnya fiskal. Sangat tepat apa yang diuraikan oleh Sudargo Gautama dan M. Anastasia Halim:

"Dengan adanya pendaftaran ini barulah dapat dijamin tentang hak-hak daripada seseorang di atas tanah. Fihak ketigapun secara mudah dapat melihat hak-hak apa atau beban-beban apa yang terletak di atas sebidang tanah. Dengan demikian terpenuhi syarat tentang pengumuman (openbaarheid), yang merupakan salah satu syarat yang melekat kepada hak-hak yang bersifat kebendaan." 16

Pendaftaran tanah selaku benda tidak bergerak dalam suatu register umum, juga memberikan pengertian, bahwa hak yang tercantum dalam register itu yang petikannya berupa buku tanah (sertifikat tanah) yang diberikan kepada yang bersangkutan, memenuhi pula unsur openbaarheid yang diminta oleh hukum benda atas hak-hak kebendaan. tanah. Akibat adanya keharusan publikasi dari hak kebendaan atas tanah, dengan ujud terdaftar dalam register umum, berakibat memiliki kekuatan mengikat terhadap pihak ketiga. Dengan "pengetahuannya" atau "pengenalannya" terhadap hak kebendaan dalam register itu, pihak ketiga menjadi terikat karenanya, dengan pengertian wajib menghormati hak kebendaan yang bersangkutan. Publikasi itu diadakan tak lain ditujukan kepada pihak ketiga. Sedang dalam hukum benda publikasi demikian itu dipaksakan adanya oleh penguasa, karena bila tidak dipenuhi, maka akibat perbuatan hukum yang menyangkut hak kebendaan itu tak akan diakui atau tidak berlaku. Menyangkut hal ini Pitlo berpendapat:

"Publikasi itu berlakunya selalu ditujukan " kepada pihak ketiga, tetapi di dalam hukum perorangan publikasi itu diurus oleh penguasa, di dalam hukum kebendaan pihak-pihak secara tak langsung dipaksa untuk mengumumkan, karena jika tidak maka akibat-akibat dari perbuatan hukum mereka menurut hukum kebendaan tidak berlaku. "77

Dengan uraian di atas, tanah sebagai benda tidak bergerak yang pada kenyataannya harus didaftar dalam register umum, sebenamya kejadian ini dapat dikatakan merupakan embrio (janin) tentang awal perlunya pembagian jenis benda ke dalam benda terdaftar - benda tidak terdaftar.

Pada zaman penjajahan Belanda dulu, kadaster ini hanya diterapkan untuk tanahtanah Eropa, sedangkan tanah adat tidak

${ }^{16}$ Sudargo Gautama dan Maria Anastasia Halim. 1981. Tafsiran Undanğ-uñdang Pokok Agraria, Alumni, Bandung. Hlm. 47.

${ }^{17}$ A. Pitlo. Op. Cit. HIm. 136. 
dikenakan. Kelanjutannya, hanya tanah Eropa itu pula yang dapat dibebani hipotek, sedang tanah adat tidak diperkenankan. Konfigurasi seperti itu pula yang mengakibatkan terjadinya dualisme hukum pertanahan. Barulah ketika pemerintah Indonesia merdeka lalu mengintrodusir UU No. 5 Tahun 1960 sebagai realisasi unifikasi hukum tanah itu diupayakan. Juga berdasarkan undang-undang tersebut maka urusan pendaftaran tanah mulai dicanangkan. Dengan pasal 19 UU No.5 Tahun 1960 pendaftaran tanah itu ditujukan untuk:

1. pengukuran, perpetaan, dan pembukuan tanah'.

2. pendaftaran hak-hak atas tanah dan peralihan hak-hak tersebut.

3. pemberian surat-surat tanda bukti hak yang berlaku sebagai alat pembuktian yang kuat.

Untuk menjabarkan serta melaksanakan pasal 19 UU No.5 Tahun 1960 itu akhirnya dikeluarkanlah Peraturan Pemerintah No.10 Tahun 1961 yang menangani masalah pendaftaran tanah secara konkrit. "Baru untuk pertama kali Indonesia mempunyai suatu lembaga pendaftaran tanah dalam sejarah pertanahan di Indonesia, dengan adanya Peraturan Pemerintah nomor 10 Tahun 1961."18 Demikian A.P. Perlindungan memberi komentarnya terhadap aturan pendaftaran tanah tersebut.

Sistem pendaftaran tanah yang dianut UU No. 5 Tahun 1960 ini bila diamati ternyata mengikuti sistem negatif. Artinya sertifikat tanah sebagai tanda bukti hak hanyalah berkekuatan sebagai alat pembuktian yang kuat sebagaimana secara hariah dapat dilihat dari bunyi pasal 19 UU No. 5 Tahun 1960. Nama yang tercantum dalam sertifikat itu diakui benar sepanjang tak terbukti sebaliknya di kemudian hari yang mungkin dilakukan oleh sesuatu pihak. Sertifikat tanah itu bukan merupakan satu-satunya alat bukti yang bersifat mutlak, justru sebaliknya baru merupakan alat bukti awal yang setiap saat bisa saja digugurkan oleh pihak lain yang terbukti memang lebih berwenang. Untuk ini A.P. Parlindungan menyatakan:

“...jelaslah kita menganut asas negatif dalam pendaftaran tanah. Asas negatif ini tercermin dalam pernyataan sebagai alat pembuktian yang kuat, bukan sebagai satu-satunya alat pembuktian. Sehingga dapat kita nyatakan dengan menganut asas negatif tersebut, bahwa sertifikat tersebut hanya atau dapat dipandang sebagai suatu bukti permulaan saja belum menjadi sertifikat itu sebagai suatu yang final sebagai bukti hak tanahnya jika kita menganut asas positif atau sebagai satusatunya alat pembuktian seperti diuraikan di atas. ${ }^{n 19}$

Dengan didaftarkannya tanah dalam register umum yang dikelola oleh Kantor Badan Pertanahan Nasional, dapat diketahui dari register tersebut siapa yang mempunyai hak atas tanah yang bersangkutan. Tentang siapa yang berwenang mempunyai Hak Milik, Hak Guna Usaha, Hak Guna Bangunan, seperti bisa ditarik dari pasal $21,30,36$ UU No. 5/1960,

${ }^{18}$ AP. Parlindungan. Op. Cit. HIm. 1.

iglbid. Him. 9. 
pada dasamya adalah warga negara Indonesia atau Badan Hukum yang bernasionalitas Indonesia.

\section{Pendaftaran Kapal Laut}

Apabila ditelusuri lebih lanjut tentang kegiatan pendaftaran benda yang diharuskan oleh penguasa, ternyata dalam Kitab UndangUndang Hukum Dagang (KUHD), dijumpai pula ketentuan yang sejenis, yakni berdasar Pasal 314 KUHD bahwa kapal Indonesia yang isi kotornya berukuran paling sedikit $20 \mathrm{~m} 3$ dibukukan dalam register kapal menurut peraturan yang akan diberikan dengan ordonansi tersendiri. Sedang ordonansi yang dimaksud tidak lain adalah Ordonansi Pendaftaran Kapal (Teboekstelling van Schepen, S. No.48/1933 jis No.1,2/1938). Pendaftaran itu dilakukan di hadapan seorang Pegawai Pembalik Nama (overschrijvingsambtenaar) yang ditunjuk. Pegawai yang dimaksud telah beberapa kali berganti, di mana pertama-tama dilaksanakan oleh Hakim dari Raad van Justitie, kemudian dialihkan kepada syahbandar, lalu beralih lagi kepada Kepala Kantor Pendaftaran Tanah, kemudian kembali lagi kepada syahbandar. ${ }^{20}$

Setelah kapal didaftar dalam register umum, agar dapat memperoleh kebangsaan Indonesia seperti yang diatur oleh Pasal 311 KUHD, harus diajukan permohonan kepada Menteri. Perhubungan dengan dilampiri beberapa surat yang diperlukan, dan salah satu di antaranya adalah sepucuk grosse akta pendaftaran. Bila telah dipenuhi, dengan cara ini maka kapal yang bersangkutan sesuai ketentuan berhak memakai bendera Indonesia. Sedangkan siapa yang berhak memiliki kapal Indonesia, sebagaimana ditentukan oleh Zeebrieven en Scheepspassen-besluit (S. 1934-78 jo. 1935-565m.b. 1 Desember 1935), pada dasarnya adalah warganegara Indonesia dan Badan Hukum Indonesia. Pengaturan tentang siapa yang boleh memiliki kapal Indonesia, pada dasarnya mempunyai hubungan yang erat dengan masalah kewenangan untuk mengagunkan kapal yang bersangkutan.

Dengan didaftar dalam register kapal, kendati tetap dapat berpindah-pindah sesuai peruntukannya, kapal yang bersangkutan tidak lagi dikenai ketentuan-ketentuan yang berlaku untuk benda bergerak lagi. Justru menyangkut kepemilikan kapal, pengalihan, pembebanan, dan bezitnya cenderung mengikuti apa yang berlaku terhadap benda tidak bergerak. Namun bukan berarti bahwa kapal tersebut lalu harus dianggap berubah sebagai benida tidak bergerak.

Pendaftaran yang dianut oleh ordonansi pendaftaran kapal mengikuti stelsel negatif, di mana hal ini dapat dilacak dari adanya fakta bahwa pegawai pembalik nama bersikap pasif. Begitu pula akta pendaftaran kapal, sekedar merupakan bukti sebuah kapal telah didaftar atau dibalik nama atas nama pemilik tertentu, dan bila ini tidak benar atau dinyatakan tidak beriaku, maka akibatnya akta itu tidak membuktikan adanya kepemilikan. Dianutnya sistem negatif dalam pendaftaran kapal ini HMN Purwosutjipto berpendapat:

${ }^{20}$ Wiwoho Soedjono. 1982. Hukum Perkapalan dan Pengangkútan Laut. Jakarta: Bina Aksara. HIm. 11. 
"Dari bunyi pasal 4 ayat 3 OPK (Ordonansi Pendaftaran Kapal) tersebut di atas ternyata, bahwa bila Pegawai Pendaftar Kapal menolak untuk membuatkan akta, yang berkepentingan bisa mengajukan banding kepada Pengadilan Negeri, yang daerah hukumnya meliputi tempat, di mana kantor Pegawai Pendaftaran Kapal itu berada. Kalau ada alasan untuk itu, Pengadilan Negeri dapat memerintahkan agar Pegawai Pendaftaran Kapal membuat akta itu. Dari ketentuan ini dapat disimpulkan, bahwa OPK menganut stelsel negatif, artinya: bagi para pihak yang tidak puas dengan keputusan Pegawai Pendaftaran Kapal, dapat mengajukan persoalannya kepada Pengadilan Negeri yang berwenang untuk minta banding. ${ }^{-21}$

Hal senada tentang dianutnya stelsel negatif terhadap pendaftaran kapal dikemukakan pula oleh Mariam Darus Badrulzaman mengatakan bahwa: pendaftaran kapal tidak memberikan jaminan bahwa orang yang namanya terdaftar adalah pemilik yang sebenarnya dari kapal tersebut. Stelsel yang tidak memberikan jaminan demikian, adalah stelsel negatif. ${ }^{22}$

Dengan peristiwa pendaftaran itu kelihatan nyata, bahwa kapal yang hakekatnya merupakan benda bergerak, setelah didaftar tidak lagi dapat dikenai ketentuan-ketentuan tentang benda bergerak. Ini merupakan gejala awal, bahwa masyarakat sebenarnya membutuhkan perlunya kualifikasi baru yakni benda terdaftar. Kapal yang telah didaftar, sebagaimana pula tanah yang juga didaftar, kalau dibebani dengan jaminan ternyata digunakan lembaga hipotek. Sedang tentang siapa yang berwenang membebani kapal tersebut dengan hipotek, ini berkait erat dengan soal siapa saja yang diperbolehkan memiliki kapal Indonesia. Kecenderungan ini tentu saja membuat posisi hipotek, mengukuhkan dirinya sebagai sarana jaminan yang. pantas untuk dihandalkan dan sangat berguna untuk dipakai sebagai pilar penyangga kegiatan ekonomi.

\section{Pendaftaran Kepemilikan Satuan Rumah Susun}

Bila taat asas disikapi dengan benar, UU No. 16 Tahun 1985 tentang rumah susun adalah penjabaran lanjut dari UU No.5 Tahun 1960 yang didasarkan pada hukum adat dengan asas pemisahan horisontal selaku prinsipnya. Bila demikian halnya, maka rumah susun bukanlah tergolong sebagai benda tanah dan punya kedudukan mandiri lepas dari tanah tempatnya berpijak. Rumah susun sebagai jenis benda mandiri berdasar Pasal 9 jo. 10 UU No. 16 Tahun 1985 kepemilikan serta pemindah-tanganannya harus didaftar dalam suatu register umum di kantor pertanahan. Dengan adanya pendaftaran tersebut, hak kebendaan yang melekat pada rumah susun dapat dengan mudah diketahui oleh pihak ketiga. Tentang siapa yang berwenang mempunyai hak atas rumah

${ }^{21} \mathrm{HMN}$. Purwosutjipto. 1980. Pengertian Pokok Hukum Dagang Indonesia. Jilid 5. Jakarta: Jambatan. HIm. 40.

${ }^{22}$ Mariam Darus Badrulzaman. Op. Cit. HIm. 98. 
susun, aturannya mengikuti ketentuan tanah, yakni warganegara dan Badan Hukum Indonesia.

Stelsel pendaftaran rumah susun inipun juga menggunakan sistem negatif, karena berdasar Pasal 9 ayat (2) UU No.16 Tahun 1985, pendaftaran itu mengikuti prosedur Peraturan Pemerintah sebagaimana dimaksud oleh Pasal 19 UU No. 5 Tahun 1960. Pada hal peraturan pemerintah yang dimaksud, yakni PP No.10 Tahun 196.1 jelas mengikuti asas negatif. Inipun dinyatakan oleh HMN Purwosutijpto bahwa: stelsel negatif ini juga dipergunakan dalam peraturan-peraturan lainnya di Republik Indonesia, misalnya UU Merek 1961 (LN 1916 - 290), P.P. No.10 Tahun 1961 (LN 1961 - 28) tentang Pendaftaran Tanah dan lain-lain. ${ }^{23}$ Selanjutnya menurut Pasal 12 jo. 13 UU No.16 Tahun 1985, rumah susun maupun satuannya dapat diagunkan. Sepanjang rumah susun itu berdiri di atas tanah dengan Hak Milik atau Hak Guna Bangunan, bila dijadikan objek jaminan lembaga hipotek yang digunakan (sekarang dengan Hak Tanggungan berdasar Pasal 27 UU No. 4 Tahun 1996).

\section{Pendaftaran Pesawat Udara}

Berdasarkan pasal 9 UU No.15 Tahun 1992 dinyatakan bahwa pesawat udara yang dioperasikan di Indonesia harus mempunyai tanda pendaftaran. Untuk keperluan itu sebagai tindak lanjutnya akan dibentuk Peraturan Pemerintah yang secara fungsional akan menjabarkan lebih lanjut dari apa yang ditetapkan oleh pasal 9 UU No. 15 Tahun 1992 tersebut. Tanda pendaftaran Indonesia hanya akan diberikan kepada pesawat udara yang memenuhi salah satu persyaratan kepemilikan yang ditetapkan, yakni:

a. dimiliki oleh warganegara Indonesia atau dimiliki oleh badan hukum Indonesia;

b. dimiliki oleh warga negara asing atau badan hukum asing dan dioperasikan oleh warganegara Indonesia atau badan hukum Indonesia untuk jangka waktu pemakaiannya minimal dua tahun secara terus menenus berdasarkan suatu perjanjian sewa beli, sewa guna usaha atau bentuk perjanjian lainnya;

c. dimiliki oleh instansi Pemerintah;

d. dimiliki oleh lembaga tertentu yang diizinkan Pemerintah.

Sedang Pasal 10 UU No.15 Tahun 1992 mengatur tentang kebangsaan pesawat udara Indonesia yang pelaksanaannya akan ditangani lebih lanjut dengan peraturan tersendiri. Dengan hadirnya ketentuanketentuan tersebut dapat disimak bahwa pesawat udara komersial yang dioperasikan di wilayah Indonesia selalu akan didaftar dalam suatu register yang sengaja disediakan untuk itu. Tanpa ada tanda pendaftaran, jelas sebuah pesawat udara tidak mungkin berfungsi sebagai sarana angkutan udara, dan juga tidak akan mungkin memperoleh tanda kebangsaan Indonesia. Jadi pendaftaran pesawat udara itu merupakan keharusan fungsional yang wajib dilakukan oleh pengelolanya sesuai peruntukan yang dikehendaki agar bisa beroperasi.

${ }^{23} \mathrm{HMN}$. Purwosutjipto. Op. Cit. HIm. 41. 
Serangkaian ketentuan seperti tersebut di atas memberikan pertanda bahwa tindakan pendaftaran terhadap pesawat udara ke dalam suatu register umum, membawa pengaruh yang tidak kecil pada posisi dan keberadaan pesawat udara sebagai salah satu jenis benda dalam konstruksi hukum. Pendaftaran itu selain menguraikan hak kebendaan yang melekat, juga memerinci spesifikasi dari seluk beluk benda tersebut dengan seksama. Uraian spesifikasi demikian ini memang penting untuk membedakannya dengan benda lain yang sekatagori, sehingga meskipun benda-benda itu dari golongan yang sama yang kadang secara lahiriah mirip, namun berdasarkan ciri dan penandaan tertentu tetap dapat dipilah-pilah. Sebagaimana lazimnya pendaftaran benda-benda lain dalam register umum, publikasi atas hak kebendaan yang melekat memang perlu diketahui oleh pihak ketiga, dan pada gilirannya terhadap "pengenalannya" itu pihak ketiga menjadi terikat karenanya dengan pengertian menjadi wajit untuk menghormati hak tersebut. Dengan pendaftaran itu pula transaksi yang dibuat oleh pemilik beserta pihak sekontrak, hubungan hukumnya tidak melulu mengikat mereka saja, tetapi juga berlaku terhadap setiap orang atau pihak ketiga. Inilah yang seringkali disebut sebagai hubungan hukum yang berlaku mutlak sebagai padanan dari hubungan hukum yang berlaku relatif. Pitlo menjelaskan tentang hal ini sebagai berikut:
"Ada hubungan-hubungan hukum yang berlaku terhadap setiap orang dan ada pula hubungan-hubungan hukum yang hanya berlaku di antara pihak-pihak.

...Publikasi adalah suatu perbuatan hukum, dengan mana orang menjadikan kedudukan hukumnya berlaku terhadap pihak ketiga. ${ }^{\text {24 }}$

Dalam kehidupan masyarakat ternyata hak kebendaan ini, di samping hak relatif, pada kenyataannya menduduki posisi yang sangat strategis. Ini tak lain hak kebendaan itu pada umumnya bersangkut paut dengan bendabenda yang memiliki nilai ekonomis relatif tinggi. Oleh sebab itu tidak heran kalau menyangkut hak kebendaan ini J.PH Suijling pernah berkomentar:

"Terlepas dari kehidupan keluarga, semua kegiatan manusia ditujukan untuk memperoleh hak-hak kebendaan (mutlak) dan hak-hak yang bersifat pribadi, sejauh undang-undang memberikan peraturan untuk itu. ... Dalam hak-hak kebendaan dan hak-hak yang bersifat pribadi tadi orang biasa melihat kelompok yang terpenting dari hak-hak subyektif, karena hak-hak termaksud menurut pendapat yang umum memberikan kepada yang berhaknya kekuasaan yang nyata atas nilai-nilai ekonomis." ${ }^{25}$

Memang pada kenyataannya bendabenda yang didaftar dalam suatu register umum, kebanyakan merupakan jenis benda

${ }^{24}$ A. Pitlo. Op. Cit. HIm. $127-133$.

${ }^{25}$ J.P.H. Sujling. 1985. Hak-hak Subyektif Dalam Hukum Perdata dan Hukum Publik Positif. (Terjemahan R. Hoesein Soemadiredja). Bandung:Armico. HIm. 3. 
yang banyak menarik minat warga masyarakat mengingat posisinya yang sangat penting dalam kehidupan sosial. Oleh sebab itulah sifat terdaftamya benda-benda itu atas perintah penguasa, dipandang memiliki pengaruh yang tidak kecil dalam tata kebutuhan khalayak ramai. Secara kebetulan pula hal yang demikian ini perlu diketahui oleh setiap orang agar mereka menjadi wajib untuk menghormatinya, sesuai sifat-sifat yang melekat pada hak kebendaan.

Kalau keberadaan penggolongan benda terdaftar - benda tidak terdaftar, hendak disepadankan dengan pembagian benda yang dikenal oleh BW, khususnya yang menyangkut pembedaan benda bergerakbenda tidak bergerak sebagai salah satu pembagian jenis benda yang sentral, memang ada sedikit sangkutannya. Ketika suatu benda sudah didaftar dalam suatu register umum, maka posisi hukumnya, sebenarnya tidak jauh berbeda dengan benda tidak bergerak yang ada dalam BW. Hal-hal diseputar peralihan kepemilikannya, cara menjaminkan ataupun aspek lainnya, terbukti tidak jauh berbeda dengan pola yang ditentukan untuk benda tidak bergerak.

Selain itu, peristiwa "pendaftaran benda" tersebut secara implisit juga menunjukkan adanya pergeseran makna dari lembaga hak milik. Dengan pendaftaran itu kepemilikan suatu benda oleh seseorang baru diakui; untuk kemudian dihormati oleh pihak lain. Demikian pula dengan fungsinya, di mana pemilik baru dapat mendayagunakan benda yang bersangkutan dalam lalu lintas kemasyarakatan manakala sudah didaftar. Kentara bahwa intervensi aspek publik sebenarnya juga telah lama terjadi atas kehidupan privat masyarakat. Sifat mutlaknya hak milik yang mulanya dianggap sakral dan tak dapat diganggu gugat, mulai luntur karena intervensi yang kian berkepanjangan.

Untuk menghindari kesimpangsiuran maka sudah selayaknya kalau Hukum Benda Nasional Indonesia segera dibenahi. Tidak hanya perlu mempertahankan penggolongan benda bergerak-benda tidak bergerak saja, tetapi sudah waktunya pula untuk mengakui adanya pembagian benda terdaftar-benda tidak terdaftar. Bahkan banyak kalangan beranggapan justru pembagian jenis benda yang terakhir ini dirasakan lebih penting pada dewasa sekarang kalau dibanding dengan pembedaan benda bergerak-benda tidak bergerak. Dengan adanya tindakan pendaftaran yang diharuskan terhadap sesuatu benda, akan membawa banyak pengaruh dalam pelbagai bidang, baik dalam hal kepemilikan, penyerahan, pengalihan hak, pembebanan, daluwarsa, penguasaan (bezit), fiskal, dan aspek publiknya. Seperti halnya pesawat udara dan kapal, setelah didaftar untuk kemudian memiliki nasionalitas, ini sangat penting dalam lapangan Hukum Internasional.

Beberapa kalangan ada yang punya anggapan, bahwa benda-benda bergerak seperti kapal dan pesawat udara yang kemudian didaftar, dianggap mempunyai posisi sebagai sui generis, yakni sesuatu yang bersifat khas, sehingga ketentuan-ketentuan umum tidak dapat diterapkan secara menyeluruh dan utuh kepadanya. Akibatnya diperlukan adanya penyimpangan penerapan ketentuan terhadapnya, dan ini dianggap sah saja kendati bergeser dari asas. Namun bila digagas lebih dalam, bukankah dengan corak khas itu berarti ada tuntutan agar kepadanya dibuatkan ruang golongan tersendiri seperti halnya katagori benda lainnya yang telah 
memiliki kamarnya masing-masing dengan pasti. Andai kata ini sudah terwujud, pada gilirannya ketentuan soal jaminan akan segera menyesuaikan diri secara runtut seiring sistemnya. Berlandas pada dalil yang berlaku dalam memaknai sistem, kalau bagian hulu, yakni hukum bendanya, dibenahi, maka alur muaranya, yakni bidang hukum jaminannya juga perlu ditangani sebagai penyesuaian. Sebab keduanya merupakan komponenkomponen yang telah menyatu dalam sistem yang utuh.

Bila hukum benda nasional telah ditangani dengan mencantumkan pembagian benda terdaftar-benda tidak terdaftar, maka eksistensi pesawat udara juga kapal menjadi terang kualifikasinya. Ketika benda-benda tersebut dibebani hipotek, keruntutan pengaturan itu dapat dilacak secara logis sesuai sistem yang ada dan berlaku. Membenahi terlebih dahulu bahagian hulu, dalam hal ini Hukum Benda, akan memudahkan penanganan ketentuanketentuan jaminan yang terletak di bagian muaranya. Apa yang sekarang ini justru kebalikannya. Beberapa produk perundangan ternyata banyak mengkait soal jaminan yang terletak di bagian muara, tanpa ada sentuhan mendasar teriebih dulu pada bagian hulu yang masih tertinggal.

Dalam era pertumbuhan ekonomi pasar seperti dewasa ini, sudah tiba saatnya bahwa pesawat udara juga kapal dikeluarkan dari karantina kualifikasi benda bergerak yang sui generis, untuk kemudian digiring ke dalam ruang barunya, yakni benda terdaftar sebagai suatu jenis pembagian benda yang sangat perlu untuk ditetapkan dalam rangka pembenahan Hukum Perdata Nasional Indonesia. Pengambilan sikap seperti ini sudah selayaknya segera direalisasi, mengingat negara-negara lain tak terkecuali Nederland telah pula menetapkan pembagian itu dalam hukum positifnya, selain tetap mempertahankan penggolongan benda bergerak-benda tidak bergerak. Bukankah sifat Hukum Benda, termasuk Hukum Jaminan, merupakan bagian hukum yang bersifat netral, sehingga pembenahannya tak akan banyak menimbulkan gejolak sosial seperti dalam hukum perkawinan dulu. Sifat netralnya Hukum Jaminan itu pernah pula dikemukakan oleh. Sri Soedewi bahwa: "hukum jaminan tergolong pada bidang hukum yang bersifat netral dan universil, tidak erat hubungannya dengan kehidupan spiritual dan budaya bangsa, dan mempunyai sifat internasional. ${ }^{{ }^{26}}$

\section{Simpulan}

Dalam pembagian jenis benda terlihat jelas betapa BW mengaturnya cukup rinci, terlebih-lebih kalau dibandingkan dengan hukum adat. Dari sekian banyak pembagian jenis-jenis benda tersebut, terbukti yang paling menonjol dan penting adalah pembangian benda bergerak - benda tidak bergerak. Akibat penggolongan ini terbukti membawa konsekuensi lanjut yang berkepanjangan baik dalam hal bezit, levering, verjaring, bezwaring, dan persoalan beslaug atau sita. Dari pembagian tersebut akhirnya juga dikenal asas perlekatan (accessie) yang memiliki posisi amat sentral dalam kerangka hukum benda. Lebih lanjut

${ }^{26}$ Sri Soedewi Machsjoen Sofwan. Op. Cit. Hlm.. 105. 
menyangkut asas perlekatan ini ternyata masih terus bergulir adanya kemungkinan untuk memperoleh hak milik atas suatu benda lewat perlekatan sebagaimana diatur oleh Pasal 584 BW.

Konsep lanjutan dari penggolongan benda membuktikan betapa suatu konsistensi itu sangat diperlukan, sehingga keruntutan pengaturan dalam suatu produk perundangundangan harus menjadi ciri utama yang tak mungkin ditawar. Aturan hukum yang mengabaikan konsistensi, tak mungkin dapat diharapkan lahirnya kepastian hukum dan keadilan seperti yang dikehendaki masyarakat.

Walaupun pembentuk BW telah memerinci pembagian jenis benda sedemikian cermat, namun sesuai perkembangan masyarakat ternyata apa yang tersedia tak juga mampu memenuhi kebutuhan. Ini dapat dipahami mengingat apa yang dihasilkan oleh manusia memang tidak mungkin lengkap dan sempurna. Penggeseran waktu acap kali segera membuahkan banyak perubahan, dan pada ujung-ujungnya pasti akan melahirkan problema baru. Demikian pula dengan masalah pembagian jenis benda ini, terbukti sesuai perkembangan zaman, masyarakat masih menghendaki adanya tambahan lagi yakni pembagian benda terdaftar - benda tidak terdaftar. Gejala ini untuk waktu sekarang dan mendatang, menampakkan tanda-tanda bahwa peran benda terdaftar semakin penting dan perlu pengaturan. Sudah demikian banyak jenis-jenis benda terdaftar memasuki arena kehidupan sosial, dan sudah kian sering memperoleh perhatian yang besar, baik dalam soal kepemilikan ataupun penjaminannya. Banyak pihak menganggap bahwa. pembagian jenis benda terdaftar — benda' tidak terdaftar perlu segera ditangani, terlebihlebih dalam upaya membenahi hukum benda nasional dengan tetap mempertahankan penggolongan benda bergerak- benda tidak bergerak.

\section{Daftar Pustaka}

Adil, Soetan Malikoel. 1962. Hak-hak Kebendaan, Pembangunan. Jakarta.

Badrulzaman, Mariam Darus. 1983. Mencari Sistem Hukum Benda Nasional. Bandung: Alumni.

Effendi, Bachtiar. 1981. Pendaftaran Tanah di Indonesia dan Peraturan-peraturan Pelaksanaannya. Bandung: Alumni.

Gautama, Sudargo dan Maria Anastasia Halim. 1981. Tafsiran Undang-undang Pokok Agraria, Alumni, Bandung.

Hunt, Alan. 1978. The Sociological Movement in Law. London: Billing and Sons Ltd.

Parlindungan, AP. 1990. Pendaftaran Tanah di Indonesia. Bandung: Mandar Maju.

Purwosutjipto, HMN. 1980. Pengertian Pokok Hukum Dagang Indonesia. Jakarta: Jambatan.

Subekti, R.. 1983. Hukum Adat Indonesia Dalam Yurisprudensi Mahkamah Agung. Bandung: Alumni.

Sofwan, Sri Soedewi Masjchoen. 1980. Hukum Jaminan di Indonesia, Pokok-pokok Hukum Jaminan dan Jaminan Perorangan. Yogyakarta: Liberty. 
Soepomo, R. 1982. Hukum Perdata Adat Jawa Barat. (terjemahan Ny. Nani Soewondo). Jakarta: Jambatan.

Syahrani, Riduan. 1985. Seluk Beluk dan Asas-asas Hukum Perdata. Bandung: Alumni.
Soedjono, Wiwoho. 1982. Hukum Perkapalan dan Pengangkutan Laut. Jakarta: BinaAksara.

Sujling, J.P.H.. 1985. Hak-hak Subyektif dalam Hukum Perdata dan Hukum Publik Positif. (Terjemahan R. Hoesein Soemadiredja). Bandung: Armico.

文壮 